\title{
MEMBANGUN KEMITRAAN BANK SYARIAH DENGAN PENDEKATAN SHARIAH MARKETING
}

\author{
Arief Yulianto \\ Universitas Negeri Semarang \\ e-mail: arief_yulianto@yahoo.co.id
}

\begin{abstract}
Amidst the competitions among shariah bank demanding the shariah bank to have marketing strategies in order to keep a sustainable relation between bank and customers. It was revealed from this research that some variables: product attributes, the quality of service to the Islamic approach to marketing, reputation, satisfaction, affective commitment, continuous commitment and customer loyalty can be accepted as the decisive variables in deciding the good marketing relationship between shariah bank and customers.

$* * *$

Di tengah-tengah persaingan di antara bank-bank syariah, dibutuhkan strategi marketing untuk mempertahankan hubungan yang berkelanjutan di antara bank dengan pelanggan. Terungkap dalam penelitian ini bahwa beberapa variabel: atribut produk, kualitas layanan dengan pendekatan Islam mengenai pemasaran, reputasi, kepuasan, komitmen yang efektif, komitmen yang berkelanjutan, dan kesetiaan pelanggan dapat diterima sebagai variabel yang menentukan hubungan pemasaran yang baik antara bank syari'ah dengan pelanggan.
\end{abstract}

Keywords: atribut produk, kualitas pelayanan, reputasi, kepuasan, komitmen, loyalitas nasabah 


\section{A. Pendahuluan}

Ditengah gejolak dan persaingan antar bank syariah diperlukan strategi pemasaran berupa relationship marketing yaitu hubungan kemitraan antara bank dengan nasabah secara dijalin secara terus menerus. Dalam jangka panjang kemitraan memungkinkan bank syariah memahami harapan serta kebutuhan nasanah. Pengalaman yang menyenangkan dari hubungan kemitraan yang dijalin oleh bank syariah dengan nasabah akan diingat oleh nasabah, hal ini dapat memelihara kesetiaan dan loyalitas nasabah.

Kualitas pelayanan merupakan senjata ampuh dalam upaya menciptakan kemitraan bank syariah dengan nasabah karena perbankan merupakan bisnis jasa yang hight contact person. Sehingga kualitas pelayanan menjadi suatu keharusan agar perbankan tetap sukses baik di tingkat operasional, manajerial dan strategik. Penelitian yang dilakukan PIMS (profit impact at market strategy) menunjukkan adanya korelasi kualitas pelayanan dengan pangsa pasar. Dengan kata lain, salah satu faktor yang dapat meningkatkan pangsa pasar adalah peningkatan kualitas pelayanan.

Menurut hasil survei SWA-Frontier mengenai customer satisfaction terhadap pelayanan kantor cabang bank di Jakarta dan Surabaya dengan jumlah 669 responden, bank syariah yang diwakili oleh Bank Muamalat merupakan bank yang kurang begitu diminati oleh responden dimana hanya 5 orang $(0,8 \%)$ memilih Bank Muamalat sebagai bank yang mampu memberi pelayanan lebih baik. ${ }^{1}$ Pada tahun 2007 Marketing Research Indonesia (MRI) mengeluarkan hasil survei terhadap bank-bank yang yang memberi kualitas pelayanan prima yang dilakukan di Kantor Cabang Jakarta, Bandung dan Solo melalui pengukuran Bank Service Excelence Monitor (BSEM) menunjukkan bank syariah tidak masuk dalam sepuluh besar bank yang mempunyai kualitas pelayanan yang prima. Oleh karena itu dengan kondisi persaingan sektor perbankan yang semakin ketat, maka bank syariah harus memperbaiki strategi usaha dengan pendekatan shariah marketing melalui peningkatan kualitas pelayanan.

\footnotetext{
${ }^{1}$ Rahman, "Membangun Kepuasan dan Loyalitas Nasabah Melalui Atribut Produk, komitmen Agama, Kualitas Jasa dan Kepercayaan pada Bank Syariah (Studi pada Bank Muamalat Cabang Semarang)," Jurnal Penelitian Walisongo, Pusat Penelitian IAIN Walisongo, 2003, h. 42-53.
} 
Shariah marketing adalah sebuah disiplin bisnis strategis yang mengarahkan proses penciptaan, penawaran dan perubahan value dari suatu inisiator kepada stakeholders-nya, yang dalam keseluruhan prosesnya sesuai dengan akad dan prinsip-prinsip muamalah (bisnis) dalam Islam. Ini artinya bahwa dalam shariah marketing, seluruh proses, baik proses penciptaan, proses penawaran, maupun proses perubahan nilai (value), tidak boleh ada hal-hal yang bertentangan dengan akad dan prinsip-prinsip muamalah yang islami. Selain itu dalam shariah marketing, bisnis yang disertai keikhlasan semata-mata hanya untuk mencari keridhaan Allah, maka seluruh bentuk transaksinya insya Allah menjadi ibadah dihadapan Allah. Ini akan menjadi bibit dan modal dasar baginya untuk tumbuh menjadi bisnis yang besar, yang memiliki spiritual brand, yang memiliki kharisma, keunggulan, dan keunikan yang tak tertandingi.

Kualitas pelayangan dengan pendekatan shariah marketing diharapkan dapat menciptakan relationship antara nasabah dan bank syariah yaitu hubungan kemitraan antara bank dengan nasabah dijalin secara terus menerus dalam usaha meningkatkan kepercayaan pada bank syariah. Pengalaman yang menyenangkan dari hubungan kemitraan yang dijalin oleh bank syariah dengan nasabah akan diingat selalu oleh nasabah, hal ini dapat memelihara kesetiaan nasabah pada akhirnya akan meningkatkan market share bank syariah. ${ }^{2}$

Menurut Fornell, ${ }^{3} \mathrm{Yi}^{4}$, Sellnes ${ }^{5}$, Cronin dan Taylor ${ }^{6}$ menunjukkan bahwa kualitas pelayanan mempunyai korelasi positif yang kuat dengan kepuasan dan loyalitas. Dalam penelitian Citra menunjukkan bahwa marketing syariah dan etika pemasaran berpengaruh signifikan terhadap kepuasan nasabah Bank Muamalat kota Semarang.7 Selain kualitas pelayanan, atribut produk islami yang ditawarkan oleh bank syariah diduga mempengaruhi kemitraan

\footnotetext{
${ }^{2}$ Ibid, h. 42-53.

${ }^{3}$ Fornell, C., "A National Customer Satisfaction Barometer: The Swedish Experience," Journal of Marketing, Vol. 56, 1992.

${ }^{4}$ Yi, Y., "A Critical Review of Customer Satisfaction," in Zeitahml VA (etal), Review of Marketing, Chicago: American Marketing Ascociation, 1988, pp. 68-123.

5 Sellnes, Fred, "An Examination of the Effect of Product Performance on Brand Reputation, Satisfaction and loyalty," European Journal of Marketing, Vol. 27 No. 9, 1993, pp. 19-35.

${ }^{6}$ Cronin and Taylor, "Measuring Service Quality: A Reexamination and Extension," Journal of Marketing, Vol. 56, No. 3, 1992, pp. 55-68.

7 Citra Fistylia, "Analisis Pengaruh Marketing Syariah dan Etika Pemasaran terhadap Kepuasan Nasabah pada Bank Muamalat di Kota Semarang," Tesis, tidak dipublikasikan, (Semarang: Universitas Islam Sultan Agung Semarang, 2008), h. 80-81.
} 
antara bank syariah dengan nasabah karena sistem operasional bank syariah berdasarkan al-Qur'an dan al-Hadits. Sehingga atribut Islam yang melekat pada produk-produk atau jasa yang ditawarkan bank syariah dapat menciptakan kemitraan antara bank syariah dengan nasabah. Hasil penelitian Rahman $^{8}$ menunjukkan atribut produk yang islami berpengaruh positif dan signifikan terhadap kepuasan nasabah bank syariah. Melalui atribut produk islami dan kualitas pelayanan dengan pendekatan shariah marketing dapat dibangun suatu kemitraan berorientasi pada hasil antara bank syariah dengan nasabah dimana dalam jangka panjang kemitraan akan menciptakan reputation yang baik bagi bank syariah, meningkatkan kepuasan nasabah, meningkatkan komitmen afektif dan komitmen kontinu yang pada akhirnya menciptakan loyalitas nasabah.

Berdasarkan kondisi-kondisi yang telah diuraikan, dapat diperoleh gambaran latar belakang atas permasalahan pada bank syariah, melalui atribut produk islami dan kualitas pelayanan dengan pendekatan shariah marketing dapat meningkatkan reputasi bank syariah, kepuasan nasabah, komitmen afektif dan kontinu yang pada akhirnya dapat mempertahankan loyalitas nasabah. Berdasarkan latar belakang masalah maka tujuan penelitian adalah untuk mengetahui pengaruh atribut produk islami, kualitas pelayanan dengan pendekatan shariah marketing, reputasi, kepuasan, komitmen afektif, komitmen kontinu terhadap loyalitas nasabah bank syariah.

Penelitian ini ditujukan untuk memperoleh bukti empirik, bahwa kemitraan bank syariah dengan nasabah dapat dibangun melalui atribut produk islami dan kualitas pelayanan dengan pendekatan shariah marketing. Jenis penelitian ini adalah penelitian kuantitatif dengan tingkat eksplanatif yaitu menjelaskan hubungan sebab akibat dari sejumlah variabel yang diteliti.

Metode pengumpulan data yang digunakan kuesioner, baik secara langsung mendatangi responden, melalui kontak person atau membentuk teamwork. Penelitian ini menggunakan nasabah tiga nasabah bank umum syariah yaitu: Bank Muamalat, Bank Syariah Mandiri Serta Bank Mega Syariah Jawa Tengah sebagai unit analisis. Instrumen yang digunakan adalah kuesioner. Kurun waktu (time horizon) yang diteliti adalah cross sectional yaitu hanya meneliti suatu waktu tertentu dengan banyak subjek (responden).

${ }^{8}$ Rahman, “Membangun Kepuasan dan Loyalitas Nasabah....” 
Populasi dalam penelitian adalah nasabah dari bank umum syariah di Jawa Tengah antara lain Bank Muamalat, Bank Syariah Mandiri dan Bank Mega Syariah. Jumlah sampel dan populasi penelitian belum diketahui secara pasti dan unit analisis penelitian ini adalah pada individu (nasabah) dengan alasan individu tersebut akan mempunyai persepsi yang bervariasi mengenai atribut produk islami, kualitas pelayanan, reputation, komitmen afektif dan kontinu nasabah, kepuasan serta loyalitas nasabah. Karena peneltian ini menggunakan anlisis Structural Equation Model (SEM) yang menggunakan sampel minimal 100 responden, maka jumlah sampel penelitian digunakan adalah 125 responden. Sesuai dengan pendapat Bacon ${ }^{9}$, besar sampel untuk penelitian multivarian minimum 100 sampel. ${ }^{10}$ Menurut Ferdinand dalam model struktural, rule of thumb besarnya sampel adalah 5 sampai 10 kali untuk setiap indikator. ${ }^{11}$ Pendapat tersebut didukung oleh pernyataan Solimun bahwa batas minimum sampel dalam model struktural sebesar 5 kali untuk setiap indikator dan maksimalnya 10 kali untuk setiap indikator. ${ }^{12}$ Adapun teknik sampling yang digunakan adalah teknik sampling nonprobabilitas, yaitu convenience sampling.

Untuk menguji hipotesis yang telah dikemukakan adalah dengan menggunakan Structur Equation Model (SEM) dengan program AMOS 4.0 Teknik Structural Equation Modeling (SEM) yang terdiri dari dua macam tenknis analisis, yaitu: Analisis faktor konfirmatori (confirmatory factor analysis) pada SEM yang digunakan untuk mengkonfirmasi faktor-faktor yang paling dominan dalam satu kelompok variabel dan Goodness of Fit dan Regression Weight pada SEM untuk menilai kekesuaian model estimasi berdasarkan tingkat pengukuran (measurement) signifikansi dari beberapa goodness of fit baik buruknya dalam suatu model, maka derajat ketepatan model ditentukan oleh cut off value-nya.

\footnotetext{
${ }^{9}$ Bacon, L.D, Using Amos for Stuctural Equation Modeling in Market Research, (Lynd Bacon \& Assocate SPSS Inc., 1997), p. 57.

${ }^{10}$ Bailey, Atherson dan Klemmack (1982) dalam Soehartono W., Metode Penelitian Sosial, (Bandung: Remaja Rosdakarya, 1988), h. 67.

${ }^{11}$ Ferdinan, A., Structural Equation Modeling dalam Penelitian Manajemen, (Semarang: Badan Penerbit Universitas Diponegoro, 2004), h. 47.

12 Solimun, Multivariate Analysis, Structure Equation Modelling (SEM), Lisrel dan Amos, (Malang: Penerbit Universitas Negeri Malang, 2002), h. 83.
} 


\section{B. Shariah Marketing}

Menurut Parasuraman, et.al, kualitas pelayanan merupakan suatu konsep secara tepat mewakili inti dari kinerja suatu jasa, yaitu perbandingan terhadap keterandalan (excellence) dalam service encounter yang dilakukan oleh konsumen. ${ }^{13}$ Menurut Bitner, kualitas pelayanan merupakan keseluruhan kesan konsumen terhadap infereoritas/superioritas organisasi beserta jasa yang ditawarkan. ${ }^{14}$ Cronin dan Taylor, menyatakan bahwa dalam ketiadaan ukuran yang objektif sebuah pendekatan yang tepat untuk memperkirakan kualitas dari suatu perusahaan jasa adalah dengan mengukur kinerja dari jasa yang dikonsumsi oleh konsumen. ${ }^{15}$

Kualitas pelayanan dapat di ketahui dengan cara membandingkat persepsi para pelanggan atas layanan yang nyata-nyata diterima atau diperoleh dengan layanan yang diharapkan. Jika kenyataan lebih dari yang diharapkan, maka layanan dapat dikatakan berkualitas sedangkan jika kenyataan kurang dari apa yang diharapkan, maka pelayanan dapat dikatakan tidak berkualitas dan apabila kenyataan sama dengan harapan maka layanan disebut memuaskan. ${ }^{16}$ Menurut Kotler terdapat lima determinan kualitas pelayanan, yaitu: (1) tangibles; (2) reliability; (3) responsiveness; (4) assurance dan (5) empathy. Pengaruh dimensi kualitas pelayanan terhadap harapan para pelanggan yang mereka terima. ${ }^{17}$

Dalam penelitian yang dilakukan oleh Parasuraman et.al yang melibatkan 800 pelanggan berusia 25 tahun ke atas dari empat perusahaan di Amerika Serikat yang ternama menunjukkan ada lima dimensi yang membentuk kualitas pelayanan antara lain: tangibles, reliability, responsiveness, assurance, dan empathy. ${ }^{18}$ Dalam penelitian ini, peneliti menggunakan kualitas pelayanan dengan pendekatan shariah marketing yang dikembangkan oleh Kertajaya dan Sula, dimensi spiritual (takwa); șiddīq, al-'adl, khidmah, menepati janji dan tidak curang serta amanah. ${ }^{19}$

\footnotetext{
${ }^{13}$ Parasuraman, A. Valarie Zeithamal and Barry, "Serqual: A Multiple-Item Scale of Measuring Cunsumer Perceptions of Service Quality," Journal of Retailing, Vol. 64, Spring,1988, pp. 12-40.

${ }^{14}$ Bitner, et.al, Service Marketing, (Singapore: Mc.Graw-Hill, 1996), pp. 132-133.

${ }^{15}$ Cronin and Taylor, "Measuring Service Quality....”

${ }^{16}$ Parasuraman, et.al, "Serqual...."

17 Kotler, Philip dan Gary Armstrong, Dasar-dasar Pemasaran, Jilid 1, Oakarta: Indeks Gramedia, 2003), h. 41.

${ }^{18}$ Parasuraman, et.al, "Serqual ...."

${ }^{19}$ Kertajaya, Hermawan dan Sula, M. Syakir, Syariah Marketing, (Bandung: Mizan Pustaka, 2006), h. 39-45.
} 


\section{Atribut Produk Islam}

Model sikap multi atribut dari Fishbein menggambarkan ancangan yang berharga untuk mengetahui hubungan diantara pengetahuan produk yang dimiliki konsumen dan sikap terhadap produk berkenaan dengan ciri atau atribut produk. Menurut Kotler produk meliputi objek fisik, pelayanan, orang, tempat organisasi dan gagasan. Sedangkan atribut produk adalah faktor yang melekat pada suatu produk..$^{20}$ Oleh karena itu, atribut produk merupakan titik tolak penilaian bagi konsumen tentang terpenuhi atau tidaknya kebutuhan dan keinginan konsumen yang diharapkan dari suatu produk yang sebenarnya, maka dapat diidentifilasikan atribut-atribut yang menyertai suatu produk. Karena bank syariah merupakan lembaga berdasarkan prinsip syariah. ${ }^{21}$ Dalam penelitian Rahman menyatakan atribut produk islami mempengaruhi kepuasan nasabah bank syariah. ${ }^{22}$

\section{Reputation (Reputasi)}

Aeker dan Keller mendefinisikan reputation atau brand reputation sebagai persepsi mengenai kualitas yang digubungkan dengan nama... ${ }^{23}$ Zeithamal $^{24}$ dan Shapiro menyatakan bahwa kualitas yang diterima dari sebuah produk atau jasa adalah berhubungan dengan reputation yang digabungkan dengan brand name. ${ }^{25}$ Dalam pemasaran, kesadaran dan image sebuah brand dan reputation produk/jasa mempengaruhi keputusan konsumen untuk membeli. Pada konteks ini reputation atau brand menjadi sebuah masalah dari sikap dan kepercayaan terhadap brand awareness dan customer satisfaction dan loyalty. ${ }^{26}$ Penelitian yang dilakukan Sellnes menyatakan reputation berdampak positif terhadap satisfaction (kepuasan).27 Penelitian Andreassen,28 Yuana menyata-

${ }^{20}$ Kotler, Philip dan Gary Armstrong, Dasar-dasar Pemasaran, h. 44.

${ }^{21}$ Atribut-atribut produk dari bank syariah harus berdasarkan syariah antara lain atribut produknya bercirikan: (1) Menghindari unsur riba; (2) menggunakan prinsip nisabah bagi hasil; (3) Menghindari unsur ketidak pastian (gharar); (4) Menghindari unsur gambling/judi, Iqbal, Z, "Islamic Financial System," Finance \& Develpoment, Juni 1997, p. 110.

${ }^{22}$ Rahman, "Membangun Kepuasan dan Loyalitas Nasabah....”

${ }^{23}$ Aaker A.D., Keller K.L, "Consumer Evaluations of Brand Extentions."

${ }^{24}$ Zeithaml, V.A., "Consumer Perceptions of Price.....”

${ }^{25}$ Shapiro, A.C., Modern Corporate Finance.

${ }^{26}$ Fornell, C., "A National Customer Satisfaction Barometer....."

${ }^{27}$ Sellnes, Fred, "An Examination of the Effect of Product Performance...." 
kan reputation mempunyai hubungan positif dengan customer satisfaction dan customer loyalty. ${ }^{29}$

\section{E. Kepuasan (Satisfaction)}

Kepuasan adalah tingkat perasaan seseorang setelah membandingkan kinerja atau hasil yang dirasakan dengan harapannya. ${ }^{30}$ Tse dan Wilton, menyatakan bahwa kepuasan atau ketidak puasan pelanggan adalah respon pelanggan terhadap evaluasi ketidaksesuaian yang dirasakan antara harapan sebelumnya dan kinerja produk atau jasa yang dirasakan setelah memakainya. ${ }^{31}$ Engel, et.al menyatakan bahwa kepuasan pelanggan merupakan evaluasi purna beli dimana alternatif yang dipilih sekurang-kurangnya memberikan hasil sama atau melampaui harapan pelanggan, sedangkan ketidakpuasan timbul apabila hasil yang diperoleh tidak memenuhi harapan pelanggan. ${ }^{32}$

Gotlieb, Grawal dan Brown menyatakan bahwa kepuasan terhadap suatu jasa berkaitan dengan proses konfirmasi dan diskonfirmasi dengan harapan. Pendapat Gotlieb, Grawal dan Brown ini didasarkan pada peradigma diskonfirmasi yang menyatakan bahwa kepuasan akan berhubungan dengan pengalaman diskorfirmasi yang merupakan pengalaman personal sesungguhnya. ${ }^{33} \mathrm{Hal}$ ini sejalan dengan pernyataan Kotler. ${ }^{34}$ Jadi kepuasan merupakan tingkat perasaan seseorang setelah membandingkan kinerja atau hasil yang dirasakan dengan harapannya. Apabila kinerja di bawah harapan, maka nasabah akan kecewa atau mengeluh. Bila kinerja sesuai dengan harapan, maka nasabah merasa puas dan jika kinerja melebihi harapannya, nasabah merasa sangat puas. ${ }^{35}$ Pelanggan yang merasa puas tidak akan

\footnotetext{
${ }^{28}$ Andreassen, Alan R and Kotler, Philip, Strategic Marketing for Non Profit Organizations, (New Jersey: Pearson Education International Inc., 2003), p. 68.

${ }_{29}$ Yuana Tobing, "Hubungan antara Performance Quality dengan Customer Oriented," Tesis, (Semarang: Universitas Diponegoro, 2000), h. 26-27.

${ }^{30}$ Oliver, R.L, "A Cognitif Model of the Antecedents and Concequences of Satisfaction Decisions," Journal of Marketing Research, Vol. 17, No 4, November 1980, p. 46-69.

31 Tse, David K and Peter C Wilton, "Models of Customer Satisfaction Formation: An Extension," Journal of Marketing Research Vol. 25, May 1988, p. 204-212.

${ }^{32}$ Engel, James F, Roger D. Blackwell and Paul W. Miniard, Consumer Behavior, (New York: Dryden Press, 1993), p. 232-233.

33 Gottlieb, J.B, Grewal, D. and Brown, S.W, "Consumer Satisfaction and Perceived Quality: Complementary or Divergen Construct?” Journal of Applied Psychology. Vol. 99 No. 6, 1994, p. 875-885.

${ }^{34}$ Kotler, Philip dan Gary Armstrong, Dasar-dasar Pemasaran, h. 64.

${ }^{35}$ Rahman, "Membangun Kepuasan dan Loyalitas Nasabah....”
} 
mengeluh dan akan menyatakan hal-hal yang baik dimana mereka bercerita kepada orang lain diluar hubungan tentang kepuasan mereka peroleh dari pemberi jasa sebaliknya sekikit pelanggan yang merasa puas (atau tidak puas) akan mengeluh. ${ }^{36}$

\section{F. Komitmen}

Komitmen merupakan esensi yang pokok dari kesuksesan hubungan kemitraan yang baik dalam jangka panjang. Komitmen yang dikeluarkan oleh kedua belah pihak dalam pertukarannya dapat menjadi pondasi dalam membangun kemitraan. Dalam hubungan kemitraan, penekanannya dalam kemitraan dilakukan hubungan secara terus menerus. Hasil yang berorientasi kemitraan merupakan pertimbangan kepercayaan yang afektif seperti tingkat kepercayaan antara mitra serta kekuatan emosional yang dirasakan oleh kedua belah pihak dan konsekuensi-konsekuensi kognitif atau evaluatif untuk tetap dalam melakukan hubungan. Donald J. Shemwell, et.al, menyebutkan kekuatan emosional dengan komitmen afektif dan kecenderungan tetap di dalam hubungan komitmen terus-menerus (kontinu). ${ }^{37}$

Kemitraan antara bank dengan nasabah lebih dari hubungan fungsional yang sederhana yang terbentuk untuk tujuan trasfer komoditi. Nasabah menaruh dana (uang) ke bank dan nasabah perlu jaminan. Kemitraan antara bank dan nasabah sangat emosional dan ikatan-ikatan itu bisa sangat kuat. Semakin puas nasabah dengan jasa yang ditawarkan bank, semakin kuat ikatan emosional atau komitmen afektifnya. Nasabah yang tida puas, mungkin merasa dihianati dan secara emosional putus asa karena ikatan afektifnya yang kuat antara nasabah dengan bank telah diabaikan. ${ }^{38}$

Proses kepuasan berkaitan dengan komitmen kontinunitas dimana aspek kognitif kepuasan mendominasi, sehingga ada jalan kecil tidak langsung dari kepuasan hingga komitmen kontinunitas di tengah komitmen afektif, celah ini didominasi oleh komponen kepuasan emosional berotak kanan. Menurut Donald J. Shemwell, et.al, karena jasa bersifat labour intensive dan

\footnotetext{
${ }^{36}$ Donald J. Shemwell, Ugur Yavas and Zaynep Bilgin, “Customer Service Provider Reationships: an Emperical Test of Model of Service Quality, Satisfaction and Reationships Oriented Outcomes," Internatioanal Journal of Service Industry Management, Vol. 9, No. 2, 1988, pp. 155-168.

${ }^{37}$ Ibid.

${ }^{38}$ Ibid.
} 
interaksi antar orang yang memainkan peranan penting, celah yang didominasi perasaan tidak langsung ini pastilah celah yang lebih kuat. ${ }^{39}$

Dalam Rational Expectation Theory yang dikemukakan dalam penelitian Yi menyatakan bahwa hubungan positif yang diharapkan antara performance quality dan customer satisfaction berada dalam garis lurus. ${ }^{40}$ Pernyataan ini telah banyak dinyatakan dalam beberapa penelitian oleh Fornell, ${ }^{41}$ Cronin dan Taylor, ${ }^{42}$ Salnes menemukan hubungan yang secara kebetulan positif antara kualitas pelayanan (kualitas jasa) dan satisfaction (kepuasan). Pengalaman yang dialami langsung memiliki dampak pada brand reputation. Persepsi kualitas digabung dengan brand akan mendorong ketika konsumen mengalami performance quality yang tinggi, atau tidak diperkuat ketika konsumen mengalami kualitas yang rendah. Penelitian dorong ketika konsumen mengalami performance quality yang tinggi, atau tidak diperkuat ketika konsumen mengalami kualitas yang rendah. Sedangkan dalam penelitian Rahman menunjukkan ada pengaruh yang signifikan kualitas pelayanan terhadap kepuasan dan loyalitas nasabah bank syariah. Kualitas jasa (kualitas pelayanan) merupakan faktor yang paling kuat pengaruhnya terhadap kepuasan dan loyalitas nasabah bank syariah. ${ }^{43}$

\section{G. Loyalitas Pelanggan (Customer Loyalty)}

Customer loyalty menggambarkan perilaku yang diharapkan sehubungan dengan penyampaian produk dan jasa. Konsumen akan loyal karena mereka puas dengan poduk atau jasa sehingga ingin meneruskan hubungan. Konsumen yang loyal melakukan lebih dari sekali dari sekedar kembali lagi, mereka juga menekankan rasa sensitif, lebih pemaaf bila kadangkala terjadi kekeliruan dalam penyampaian produk dan jasa, dan meraka melakukan iklan dari mulut ke mulut seperti yang dikembangkan oleh Straube. ${ }^{44}$ Secara universal satsfaction dan reputation mempunyai hubungan positif, hal ini

${ }^{39}$ Ibid.

${ }^{40}$ Yi, Y, "A Critical Review of Customer Satisfaction.”

${ }^{41}$ Fornell, C., "A National Customer Satisfaction Barometer ...."

${ }^{42}$ Cronin and Taylor, "Measuring Service Quality ....”

${ }^{43}$ Rahman, "Membangun Kepuasan dan Loyalitas Nasabah....”

${ }^{44}$ Straube, Peter, "Why Customer Satisfaction May not Mean Loyalty," Nation's Restaurant News, Vol. 31, July 1997, pp. 32-36. 
sesuai dengan pendapat Cronin dan Taylor, ${ }^{45}$ Fornell, ${ }^{46}$ Sellnes, ${ }^{47} \mathrm{Yi}^{48}{ }^{48}$ Andreassen, ${ }^{49}$ Parasuraman, ${ }^{50}$ Shemwell, ${ }^{51}$ Oliver, ${ }^{52}$ Mowen, ${ }^{53}$ dan Rahman. ${ }^{54}$ Customer loyalty pada hakikatnya akan mencerminkan sikap yang brand loyalty. Adapun brand loyalty didefinisikan sebagai tingkat dimana konsumen mempertahankan sikap positif terhadap sebuah brand, memiliki komitmen dan berharap terus-menerus menggunakan atau memakai produk barang atau jasa dimasa yang depan. Dengan demikian brand loyalty dipengaruhi langsung oleh satisfaction pada brand yang dihimpun melalui waktu. ${ }^{55}$

Model konseptual yang didasarkan pada telaah pustaka dan penelitianpenelitian yang pernah dilakukan, maka kerangka pemikiran teoritis dalam penelitian disajikan pada gambar 1.

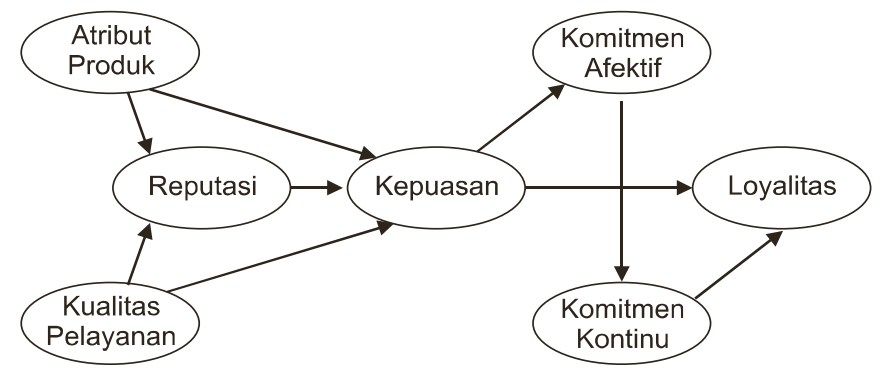

Gambar 1.

Kerangka Pemikiran Teoritis

\footnotetext{
${ }^{45}$ Cronin and Taylor, "Measuring Service Quality...."

${ }^{46}$ Fornell, C., "A National Customer Satisfaction Barometer...."

${ }^{47}$ Sellnes, Fred, "An Examination of the Effect of Product Performance...."

48 Yi, Y., "A Critical Review of Customer Satisfaction,"

${ }^{49}$ Andreasen, Alan R and Kotler, Philip, Strategic Marketing for Non Profit Organizations.

50 Parasuraman, et.al, "Serqual ...."

51 Donald J. Shemwell, et.al, “Customer Service Provider Reationships.....”

52 Oliver, R.L, "A Cognitif Model of....”

53 Mowen, Customer Behavior, (New Jersey: Prentice Hall Inc., 1995),. h. 84.

54 Rahman, "Membangun Kepuasan dan Loyalitas Nasabah...."

55 Mowen, Customer Behavior.
} 


\section{H. Pembahasan}

Dengan demikian keseluruhan model (full model) tidak dapat diterima karena belum memenuhi kelayakan sebuah model, bak secara regression weight maupun goodness of fit index. Untuk itu perlu dilakukan modifikasi terhadap model yang dikembangkan supaya memiliki tingkat prediksi yang diharapkan. Model keseluruhan penelitian disajikan pada gambar 2 dan tabel 1 sebagai berikut:

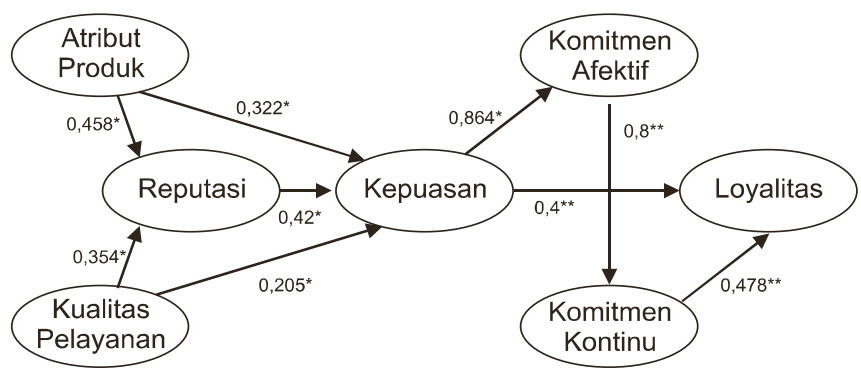

Gambar 2.

Model Penelitian

Tabel 1.

Hasil Uji Regression Weight untuk Keseluruhan Model (Full Model)

\begin{tabular}{lclcccc}
\hline & Hubungan antar Variabel & Estimate & S.E. & C.R. & P \\
\hline reputation & $<-$ & kualitas_pelayanan & 0,354 & 0,179 & 1,978 & $0,048^{*}$ \\
reputation & $<-$ & atribut_produk & 0,458 & 0,181 & 2,532 & $0,011^{*}$ \\
kepuasan & $<-$ & atribut_produk & 0,322 & 0,135 & 2,387 & $0,017^{*}$ \\
kepuasan & $<-$ & kualitas_pelayanan & 0,205 & 0,118 & 1,794 & 0,081 \\
kepuasan & $<-$ & reputation & 0,339 & 0,163 & 2,083 & $0,037^{*}$ \\
komitmen_afektif & $<-$ & kepuasan & 0,864 & 0,124 & 6,963 & 0 \\
komitmen_kontinu & $<-$ & komitmen_afektif & 0,8 & 0,196 & 4,073 & 0 \\
loyalitas & $<-$ & kepuasan & 0,4 & 0,201 & 1,985 & $0,047^{*}$ \\
loyalitas & $<-$ & komitmen_kontinu & 0,478 & 0,226 & 2,119 & $0,034^{*}$ \\
\hline
\end{tabular}

Sumber: Data penelitian diolah.

Pada tabel 1 menunjukkan bahwa semua hubungan variabel penelitian mempunyai CR-critical ratio diatas 1,96 sehingga secara regression weigth 
hubungan seluruh variabel penelitian signifikan. Hasil uji goodness of fit measure untuk keseluruhan model (full model) disajikan pada tabel 2.

Tabel 2.

Goodness of Fit Measure

\begin{tabular}{lcccl}
\hline Fit Measure & Default model & Saturated & Independence & Macro \\
Discrepancy & 110.482 & 0 & 932.326 & CMIN \\
Degrees of freedom & 80 & 0 & 105 & DF \\
P & 0.014 & & 0 & P \\
Number of parameters & 40 & 120 & 15 & NPAR \\
Discrepancy / df & 1.381 & & 8.879 & CMINDF \\
RMR & 0.078 & 0 & 0.631 & RMR \\
GFI & 0.902 & 1 & 0.286 & GFI \\
Adjusted GFI & 0.853 & & 0.184 & AGFI \\
Tucker-Lewis index & 0.952 & & 0 & TLI \\
Comparative fit index & 0.963 & 1 & 0 & CFI \\
Parsimony-adjusted NFI & 0.672 & 0 & 0 & PNFI \\
Parsimony-adjusted CFI & 0.734 & 0 & 0 & PCFI \\
RMSEA & 0.055 & & 0.252 & RMSEA \\
\hline
\end{tabular}

Sumber: Data penelitian diolah.

Berdasarkan hasil analisis penelitian yang telah dilakukan, selanjutnya akan dilakukan pembahasan terhadap hasil analisis tersebut, dengan melihat hubungan kausalitas yang terjadi sebagai pembuktian hipotesis yang diangkat dalam penelitian ini. Teori-teori ataupun hasil penelitian empirik yang telah dilakukan oleh peneliti sebelumnya akan digunakan dalam melakukan pembahasan hasil penelitian, apakah teori atau hasil penelitian empirik tersebut mendukung atau bertentangan dengan hasil pengujian hipotesis yang dilakukan dalam penelitian yang dimiliki oleh penelitian ini.

\section{Pengaruh Kualitas Pelayanan dengan Pendekatan Shariah Marketing terhadap Reputasi Bank Syariah}

Dari tabel 1 menunjukkan bahwa kualitas pelayanan dengan pendekatan shariah marketing berpengaruh positif dan signifikan karena mempunyai CRcritical ratio 1,978 atau ditatas 1,96 dengan koefisien jalur 0,354 dengan tingkat probabilitas 0,048. secara logika dalam kondisi persaingan yang semakin ketat, setiap perusahaan harus mampu bertahan hidup, bahkan harus dapat terus 
berkembang. Bank syariah yang mempunyai kualitas pelayanan prima akan memenangi perasingan di industri bank. Bahkan tidak hanya itu saja, bank yang mempunyai kualitas pelayanan yang prima dapat membangun loyalitas nasabah. Dalam pemasaran, kesadaran dan image sebuah brand dan reputation produk/jasa mempengaruhi keputusan konsumen untuk membeli. Pada konteks ini reputation atau brand menjadi sebuah masalah dari sikap dan kepercayaan terhadap brand awareness dan customer satisfaction dan loyalty. ${ }^{56}$ Penelitian yang dilakukan Sellnes ${ }^{57}$ menyatakan reputation berdampak positif terhadap satisfaction (kepuasan). Penelitian Andreassen, ${ }^{58}$ Yuana ${ }^{59}$ menyatakan reputation mempunyai hubungan positif dengan customer satisfaction dan customer loyalty. Dalam penelitian ini, peneliti mengembangkan pelayanan dengan konsep shariah marketing. Dimana Menurut Kertajaya dan Sula, ${ }^{60}$ dalam shariah marketing, seluruh proses, baik proses penciptaan, proses penawaran, maupun proses perubahan nilai (value) tidak boleh ada hal-hal yang bertentangan dengan akad dan prinsip-prinsip muamalah yang islami. Di sinilah letak orisionalitas penelitian ini, karenanya layak untuk diteruskan guna memperkaya khazanah studi tentang hubungan kemitraan (realtionship) bank syariah dengan nasabah. Dalam shariah marketing banyak yang mengatakan pasar syariah, adalah pasar yang emosional (emotional market), sedangkan pasar konvensional adalah pasar yang rasional (rational market). Maksudnya orang tertarik untuk berbisnis pada pasar syariah karena alasan-alasan keagamaan (dalam hal ini agama Islam) yang lebih bersifat emosional, bukan karena ingin mendapatkan untung secara finansial yang bersifat rasional. Sebaliknya pada pasar konvensional atau non-syariah, orang ingin mendapatkan keuntungan yang sebesar-besarnya, tanpa terlalu peduli apakah bisnis yang digelutinya tersebut mungkin menyimpang atau malah bertentangan dengan ajaran agama .

Konsep pemasaran syariah ada empat karakteristik pemasaran syariah yang dapat menjadi panduan bagi para pemasar sebagai berikut: Pertama, theistis (rabbaniyyah) dimana salah satu ciri khas pemasaran syariah yang tidak dimiliki dalam pemasaran konvensional yang dikenal selama ini adalah

\footnotetext{
56 Fornell, C., "A National Customer Satisfaction Barometer....”

${ }^{57}$ Sellnes, Fred, "An Examination of the Effect of Product Performance...."

${ }^{58}$ Andreasen, Alan R and Kotler, Philip, Strategic Marketing for Non Profit Organizations.

59 Yuana Tobing, "Hubungan Antara Performance Quality...."

${ }^{60}$ Kertajaya, Hermawan dan Sula, M. Syakir, Syariah Marketing.
} 
sifatnya yang religius (dīniyyah). Kondisi ini tercipta tidak karena keterpaksaan, tetapi berangkat dari kesadaran akan nilai-nilai religius, yang dipandang penting dan mewarnai aktivitas pemasaran agar tidak terperosok ke dalam perbuatan yang merugikan orang lain. Kedua, etis (akhlāqiyyah) dimana pemasaran syariah selain karena teistis (rabbaniyyah), juga karena ia sangat mengedepankan masalah akhlak (moral, etika) dalam seluruh aspek kegiatannya. Ketiga, realistis (al-waqi'iyyah) dimana pemasaran syariah adalah konsep pemasaran yang fleksibel, sebagaimana keluasan dan keluwesan syariah Islamiyah yang melandasinya. Hal ini dicontohkan oleh Nabi untuk bisa bersikap lebih bersahabat, santun, dan simpatik terhadap saudarasaudaranya dari umat lain. Keempat, humanistis (insāniyyah) merupakan syariah diciptakan untuk manusia agar derajatnya terangkat, sifat kemanusiaannya terjaga dan terpelihara, serta sifat-sifat kehewanannya dapat terkekang dengan panduan syariah.

Karena persaingan antar bank syariah yang semakin ketat, dengan menerapkan shariah marketing, dimana shariah marketing merupakan senjata ampuh dalam keunggulan bersaing dalam menjalin kemitraan (relationship) dengan nasabah. Bank syariah yang dapat mempertahankan hubungan kemitraan (relationship) secara terus-menerus dengan nasabahnya yang dapat bertahan dan dapat memenangkan persaingan yang pada akhirnya dapat meningkatkan market share-nya. Sehingga shariah marketing menjadi suatu keharusan diimplementasikan agar bank syariah tetap eksis baik di tingkat operasional, manajerial maupun dalam keunggulan bersaing. Hal ini merupakan awal dalam membangun hubungan kemitraan (relationship) yang berkelanjutan atau kemitraan antara nasabah dan bank syariah yang pada akhirnya dapat meningkatkan reputasi bank syariah, sehingga hipotesa yang dibangun dalam peelitian yaitu kualitas pelayanan berpengaruh signifikan terhadap reputation bank syariah dapat diterima (Ha: diterima)

\section{Pengaruh Kualitas Pelayanan dengan Pendekatan Shariah Marketing terhadap Kepuasan Nasabah Bank Syariah}

Dari tabel 1 menunjukkan bahwa kualitas pelayanan dengan pendekatan shariah marketing berpengaruh positif dan kurang signifikan karena mempunyai CR-critical ratio 1,794 atau di bawah 1,96 yang memiliki koefisien jalur 0,205 dengan tingkat probabilitas 0,081 atau siginifikan pada level $\alpha=10 \%$. Pada hal secara universal dapat dijelaskan bahwa kualitas pelayanan dan 
kepuasan nasabah mempunyai korelasi yang positif dan signifikan. ${ }^{61}$ Beberapa peneliti terdahulu menyatakan bahwa persepsi kualitas pelayanan merupakan hasil kepuasan. ${ }^{62}$ Sehingga hipotesa yang dibangun oleh peneliti yaitu kualitas pelayanan berpengaruh secara signifikan terhadap kepuasan nasabah tidak terbukti (Ha: ditolak).

Beradasarkan hasil survei di lapangan menunjukkan bahwa 48,8\% menyatakan bahwa bank syariah sudah mengimplementasikan shariah marketing, dan $31,2 \%$ tidak menjawan serta $20 \%$ menyatakan belum. Besarnya responden tidak menjawab tentang shariah marketing merupakan indikasi bahwa responden belum memahami tentang shariah marketing, sehingga terjadi kesalahan persepsi responden tentang pelayanan dengan pendekatan shariah marketing. Hal ini dibuktikan dengan jawaban responden yang menyatakn bahwa bank syariah telah mengimplementasikan pelayanan dengan pendekatan shariah marketing. Sebagian besar responden atau 33,3\% menyatakan bank syariah menggunakan bagi hasil, 18,8\% tidak mengandung riba dan 16\% menyatakan tidak mengandung riba. Padahal semua jawaban responden menyangkut persepsi terhadap atribut produk bank syariah bukan tentang kualitas pelayanannya. Terdapat beberapa pendekatan dalam kualitas pelayanan, Parasuraman, Leonard L. Berry dan Valeria yang dikenal PBZ. Pandangan PBZ mengenai service quality didasari oleh suatu model yang mereka rancang dan mereka sebut sebagai conceptual model of service quality dengan indikatorindikator pelayanan banyak mengacu pada pendapat Kotler dimana terdapat lima determinan service quality (1) tangibles; (2) reliability; (3) responsiveness; (4) assurance dan (5) empathy 63 yang telah banyak digunakan oleh peneliti-peneliti terdahulu. Cronin and Taylor, Sellnes, serta Parasuraman etal melakukan penelitian dengan melibatkan 800 pelanggan berusia 25 tahun ke atas dari empat perusahaan di Amerika Serikat yang ternama menunjukkan ada lima dimensi yang membentuk service quality antara lain: (1) tangibles, yaitu kemampuan untuk memberikan pelayanan sesaui dengan yang dijanjikan; (2) reliability, yaitu kemampuan untuk memberikan pelayanan sesuai dijanjikan dengan tepat dan

${ }^{61}$ Lihat kembali: Fornell, "A National Customer Satisfaction Barometer...."; Yi, "A Critical Review of Customer Satisfaction,"; Sellnes, Fred, "An Examination of the Effect of ProductPerformance..."; Cronin dan Taylor, "Measuring Service Quality..." "Serqual ...."

62 Lihat Bitner, et.al, Service Marketing; Oliver R.L, "A Cognitif Model of..."; Parasuraman, et.al,

63 Kotler, Dasar-dasar Pemasaran, h. 561. 
terpercaya; (3) responsiveness, yaitu keinginan untuk membantu para pelanggan dan memberikan pelayanan dengan sebaik mungkin; (4) assurance, yaitu pengetahuan dan kesopansantunan para pegawai perusahaan serta kemampuan untuk membutuhkan rasa percaya para pelanggan kepada perusahaan dan (5) empathy, yaitu perhatian yang tulus yang diberikan kepada pelanggan.

Sedangkan dalam penelitian ini menggunakan dimensi-dimensi yang dikembangkan oleh Kertajaya dan Sula64, yaitu: (1) petugas pelayanan memiliki kepribadian spiritual (taqwa); (2) Berperilaku baik dan sopan (siddīq). Sesungguhnya Allah tidak menyukai orang-orang yang sombong yang membanggakan diri." Al-Quran juga mengharuskan pemeluknya untuk berlaku sopan dalam setiap hal; bahkan dalam melakukan transaksi bisnis dengan orang-orang bodoh (sufaha), tetap harus berbicara dengan ucapan dan ungkapan yang baik; (3) Berperilaku/bersikap adil (al-'adl). Berbisnislah kalian secara adil, demikian firman Allah: "Berusahalah secara adil dan kamu tidak boleh bertindak dengan tidak adil." (4) Bersikap melayani dan rendah hati (khidmah). Orang yang beriman diperintahkan untuk bermurah hati, sopan, dan bersahabat saat berelasi dengan mitra bisnisnya; (5) Menepati janji dan tidak curang, āmanah bermakna keinginan untuk memenuhi sesuatu sesuai dengan ketentuan. Secara umum, amanah dari Allah SWT. Kepada manusia ada dua, yaitu ibadah dan khalifah; (6) Jujur dan terpercaya (al-ämanah) Di antara akhlak yang harus menghiasi bisnis syariah dalam setiap gerak-geriknya adalah kejujuran. Dimensi-dimensi yang dikembangkan oleh Hermawan dan Sula cenderung emosional sehingga pengukuran indikatornya sulit dilakukan atau terjadi bias. Oleh karena itu diperlukan sutu rekonstruksi terhadap indikator-indikator yang digunakan dalam mengukur kualitas pelayanan dengan pendekatan shariah marketing agar terukur. Atau bakan shariah marketing belum dilaksanakan atau di implementasikan oleh bank syariah dalam membengun hubungan kemitraan dengan nasabah, karena penelitian ini diasumsikan bahwa bank syariah telah menerapkan shariah marketing dalam menjalin kemitaan dengan nasabah, sehingga penelitian tentang apakah shariah marketing sudah diimplementasikan oleh bank syariah dalam menjalin kemitraan dengan nasabah perlu dilakukan untuk penelitian di masa yang akan datang.

${ }^{64}$ Kertajaya, Hermawan dan Sula, M. Syakir, Syariah Marketing. 


\section{Pengaruh Atribut Produk Islami terhadap Reputasi Bank Syariah}

Pada tabel 1 menujukkan bahwa pengaruh atribut produk islami terhadap reputasi bank syariah signifikan karena mempunyai CR-critical ratio 2,532 atau di atas 1,96 miliki koefisien jalur sebesar 0,458 dengan tingkat probabilitas 0,011 . Dalam teori perilaku konsumen, salah satu sarana bagi konsumen untuk menilai keandalan dan integritas patner dalam pertukaran adalah atribut produk. Atribut produk mempunyai pengaruh terhadap persepsi nasabah bank syariah terhadap penggunaan suatu jasa atau produk bank syariah. Hal itu disebabkan secara fisik atribut produk membawa berbagai macam manfaat yang dibutuhkan dan yang diinginkan oleh nasabah. Oleh karena itu pengembangan produk dan jasa memerlukan pendefinisian manfaat dan dikonfirmasi melalui atribut produk.

Atribut produk merupakan fitur (baik yang berwujud maupun tidak berwujud) suatu barang dan jasa yang dapat dinilai oleh pelanggan. Atribut produk adalah unsur-unsur yang dipandang penting oleh kansumen dan dijadikan dasar pengabilan keputusan pembelian. Jadi atribut produk merupakan satu kesatuan dari bermacam-macamt aribut yang membentuknya, dimana masing-masing atribut mempunyai kapasitas yang berbeda-beda dalm memberikan keputusan pemakai produk tersebut.

Melihat model sikap multi atribut dari Fishbein menggambarkan ancangan yang berharga untuk mengetahui hubungan diantara pengetahuan produk yang dimiliki konsumen dan sikap terhadap produk berkenaan dengan ciri atau atribut produk. Atribut produk merupakan titik tolak penilaian bagi konsumen tentang terpenuhi atau tidaknya kebutuhan dan keinginan konsumen yang diharapkan dari suatu produk yang sebenarnya, maka dapat diidentifilasikan atribut-atribut yang menyertai suatu produk. Oleh karena bank syariah merupakan lembaga berdasarkan prinip syariah, maka atributatribut produk dari bank syariah harus berdasarkan syariah antara lain atribut produknya bercirikan: (1) Menghindari unsur riba; (2) menggunakan prinsip nisabah bagi hasil; (3) Menghindari unsur ketidakpastian (gharar); (4) Menghindari unsur gambling/judi.65 Dalam penelitian Rahman ${ }^{66}$ me-

${ }^{65}$ Iqbal, Z, “Islamic Financial System”, Finance \& Develpoment, Juni 1997.

${ }^{66}$ Rahman, "Membangun Kepuasan dan Loyalitas Nasabah...." 
nyatakan atribut produk islami mempengaruhi reputasi bank syariah, sehingga hipotesa yang dibangun dapat diterima (Ha: diterima).

Oleh karena operasionalisasi bank syariah berprinsip pada syariah sehingga atribut produk berdasarkan prinsip-prinsip syariah merupakan keunggulan bagi bank syariah daam mengembangkan produknya. Atribut produk yang kuat berkualitas, teruji, dan bernilai tinggi terbukti tidak hanya sukses mengalahkan hitungan-hitungan rasional, tetapi juga canggih mengolah sisi-sisi emosional nasabah yang notabene merupakan nasabah emosional dimana nasabah dalam melakukan kemitraan memandang prinsipprinsip syariah yang ada pada produk-produk merupakan alasan utama mengapa nasabah memilih bank syariah sebagai mitra uasaha bagi mereka. Hal ini dibuktikan dengan hasil penelitian yang dilakukan oleh bank Indonesia yang bekerja sama dengan Perguruan Tinggi tentang preferen masyarakat terhadap bank syariah, ternyata sebagian besar masyarakat melakukan kemitraan karena bank syariah operasionalisasinya berdasarkan prinsip syariah (tidak mengandung riba, maysir, gharar). Oleh karena itu atribut Islam yang melekat pada produk bank syariah dapat memiliki nilai tinggi karena ada brand building activity yang bukan sekadar berdasarkan emosional nasabah, tetapi merupakan segala macam usaha dan kemudahan yang melekat pada produk bank syariah untuk memperkuat reputasi atau image bank syariah.

\section{Pengaruh Atribut Produk Islami terhadap Kepuasan Nasabah Bank Syariah}

Pada tabel 1 menujukkan bahwa pengaruh atribut produk islami terhadap kepuasan nasabah bank syariah signifikan karena mempunyai CRcritical ratio 2,387 atau diatas 1,96 miliki koefisien jalur sebesar 0,322 dengan tingkat probabilitas 0,017. Kepuasan pelenggan merupakan suatu tingkatan dimana kebutuhan, keinginan dan harapan dari pelenggan dapat terpenihi yang akan mengakibatkan terjadinya pembelian ulang atau kesetiaan yang berlanjut. Faktor yang paling penting untuk menciptakan kepuasan konsumen adalah kinerja dari agen yang biasanya diartikan dengan kualitas dari agen tersebut. ${ }^{67}$

${ }^{67}$ Mowen, J.C, Customer Behavior. 
Produk jasa berkualitas mempunyai peranan penting untuk membentuk kepuasan pelanggan. Semakin berkualitas produk dan jasa yang diberikan, maka kepuasan yang dirasakan oleh pelanggan semakin tinggi. Bila kepuasan pelanggan semakin tinggi, maka dapat menimbulkan keuntungan bagi badan usaha tersebut. Pelanggan yang puas akan terus melakukan pembelian pada badan usaha tersebut. Demikian pula sebaliknya jika tanpa ada kepuasan, dapat mengakibatkan pelanggan pindah pada produk lain.

Dalam pokok-pokok hasil penelitian Bank Indonesia tahun 2000 yang keenam menyatakan bahwa nasabah yang menggunakan jasa bank syariah, sebagian memiliki kecenderungan untuk berhenti menjadi nasabah antara lain karena keraguan akan konsistensi penerapan prinsip syariah. Kepatuhan dan kesesuaian Bank terhadap prinsip syariah sering dipertanyakan oleh para nasabah. Secara implisit hal tersebut menunjukkan bahwa praktik perbankan syariah selama ini kurang memperhatikan prinsip-prinsip syariah. Oleh karena itu pada penelitian ini terbukti bahwa atribut produk islami berpenfaruh signifikan terhadap kepuasan nasabah bank syariah.

Atribut produk adalah karakteristik-karakteristik produk yang ada dibenak dan dijelaskan oleh nasabah. Nilai konsekuensi adalah penilaian subjektif nasabah sebagai konsekuensi dari penggunaan atau pemanfaatan produk bank syariah. Model konseptual terhadap variable nilai atribut produk, mengacu pada dimensi nilai atribut produk yang berdasarkan prinsip syariah bercirikan: (1) menghindari unsur riba; (2) menggunakan prinsip nisbah bagi hasil; (3) menghindari unsur ketidak pastian (gharar); (4) menghindari unsur gambling/judi. ${ }^{6}$

Dalam pokok-pokok hasil penelitian Bank Indonesia tahun 2000 menyatakan bahwa nasabah yang menggunakan jasa bank syariah, sebagian memiliki kecenderungan untuk berhenti menjadi nasabah antara lain karena keraguan akan konsistensi penerapan prinsip syariah. Kepatuhan dan kesesuaian Bank terhadap prinsip syariah sering dipertanyakan oleh para nasabah. Secara Implisit hal tersebut menunjukkan bahwa praktik perbankan syariah selama ini kurang memperhatikan prinsip-prinsip syariah. Dalam penelitian Rahman ${ }^{69}$ menyatakan atribut produk islami mempengaruhi

${ }^{68}$ Iqbal, Z, "Islamic Financial System".

${ }^{69}$ Rahman, “"Membangun Kepuasan dan Loyalitas Nasabah ....” 
kepuasan nasabah bank syariah. Oleh karena itu pada penelitian ini terbukti bahwa atribut produk islami berpenfaruh signifikan terhadap kepuasan nasabah bank syariah (Ha: diterima).

\section{Pengaruh Reputasi terhadap Kepuasan Nasabah Bank Syariah}

Pada tabel 1 menujukkan bahwa reputasi bank syariah terhadap kepuasan nasabah bank syariah signifikan karena mempunyai CR-critical ratio 2,083 atau di atas 1,96 miliki koefisien jalur sebesar 0,339 dengan tingkat probabilitas 0,037. Reputation atau brand reputation didefinisikan oleh Aeker dan Keller, sebagai persepsi mengenai kualitas yang digubungkan dengan nama. ${ }^{70}$ Menurut Zeithamal ${ }^{71}$ dan Shapiro ${ }^{72}$ kualitas yang diterima dari sebuah produk atau jasa adalah berhubungan dengan reputation yang digabungkan dengan brand name. Dalam pemasaran, kesadaran dan image sebuah brand dan reputation produk/jasa mempengaruhi keputusan konsumen untuk membeli. Pada konteks ini reputation atau brand menjadi sebuah masalah dari sikap dan kepercayaan terhadap brand awareness dan customer satisfaction dan loyalty.

Penelitian yang dilakukan Sellnes ${ }^{73}$ menyatakan reputation berdampak positif terhadap satisfaction (kepuasan). Penelitian Rahman ${ }^{74}$ menyatakan terjadi hubungan yang signifikan antara reputasi dengan kepuasan nasabah Bank Muamalat. Penelitian Andreassen ${ }^{75}$, Yuana ${ }^{76}$ menyatakan reputation mempunyai hubungan positif dengan customer satisfaction dan customer loyalty. Oleh karena itu, hipotesis yang dikembangkan bahwa reputation yang baik dari bank syariah berpengaruh terhadap kepuasan yang dirasakan nasabah bank syariah (Ha: diterima).

\footnotetext{
70 Aaker A.D., Keller K.L, "Consumer Evaluations of Brand Extentions."

71 Zeithaml, V.A., “Consumer Perceptions of Price....”

72 Shapiro, A.C., Modern Corporate Finance.

${ }^{73}$ Sellnes, Fred, "An Examination of the Effect of Product Performance...."

${ }^{74}$ Rahman, "Membangun Kepuasan dan Loyalitas Nasabah...”

${ }^{75}$ Andreasen, Alan R and Kotler, Philip, Strategic Marketing for Non Profit Organizations.

76 Yuana Tobing, "Hubungan Antara Performance Quality...."
} 


\section{Pengaruh Kepuasan terhadap Komitmen Afektif Nasabah Bank Syariah}

Pada tabel 1 menujukkan bahwa kepuasan berpengaruh terhadap komitmen afektif nasabah bank syariah signifikan karena mempunyai CRcritical ratio 6,963 atau di atas 1,96 miliki koefisien jalur 0,864 dengan tingkat probabilitas 0,000 . Hal ini menunjukkan bahwa hipotesis yang menyatakan bahwa kepuasan berpengaruh signifikan terhadap komitmen afektif nasabah bank syariah terbukti kebenarannya (Ha: diterima).

Hasil penelitian ini secara empiris mendukung beberapa hasil penelitian yang dilakukan oleh beberapa peneliti yang menguji adanya pengaruh kepuasan terhadap komitmen yaitu Boonajsevee (2005), dan Hennig-Thurau et.al (2002). Hasil penelitian mereka menunjukkan bahwa peningkatan kepuasan pelanggan akan membangun komitmen yang lebih kuat terhadap suatu bank. Jadi nasabah akan puas apabila bank dapat memenuhi atau melebihi harapan mereka dan kurang suka mengembangkan kemitraan (relationship) yang baru dengan bank lain apabila sudah memiliki kedekatan emosional yang kuat dengan suatu bank tertentu.

Komitmen merupakan esensi yang pokok dari kesuksesan hubungan kemitraan (relationship) yang baik dalam jangka panjang, dimana komitmen yang dikeluarkan oleh kedua belah pihak dalam pertukarannya dapat menjadi pondasi dalam membangun kemitraan. Dalam hubungan kemitraan, penekanannya dalam kemitraan dilakukan hubungan secara terus menerus. Hasil yang berorientasi kemitraan merupakan pertimbangan kepercayaan yang afektif seperti tingkat kepercayaan antara mitra serta kekuatan emosional yang dirasakan oleh kedua belah pihak dan konsekuensi-konsekuensi kognitif atau evaluatif untuk tetap dalam melakukan hubungan. Donald J. Shemwell, etal, ${ }^{77}$ menyebutkan kekuatan emosional dengan komitmen afektif dan kecenderungan tetap didalam hubungan komitmen terus-menerus (kontinu).

Kemitraan antara bank dengan nasabah lebih dari hubungan fungsional yang sederhana yang terbentuk untuk tujuan trasfer komoditi. Nasabah menaruh dana (uang) ke bank dan nasabah perlu jaminan. Kemitraan antara ships...."

77 Donald J. Shemwell, Ugur Yavas \& Zaynep Bilgin, “Customer Service Provider Reation- 
bank dan nasabah sangat emosional dan ikatan-ikatan itu bisa sangat kuat. Semakin puas nasabah dengan jasa yang ditawarkan bank, semakin kuat ikatan emosional atau komitmen afektifnya. Nasabah yang tida puas, mungkin merasa dihianati dan secara emosional putus asa karena ikatan afektifnya yang kuat antara nasabah dengan bank telah diabaikan.

Hasil ini memberikan indikasi bahwa tingkat kepuasan debitur sangat menentukan tingkat komitmen afektih pada bank syariah. Hal ini dapat disebabkan oleh karena kepuasan nasabah terhadap bank syariah akan menuntun mereka pada tingkat komitmen, atau nasabah yang memperoleh rasa puas dari mengunakan produk atau jasa bank syariah akan yakin untuk mempertahankan hubungan dengan bank syariah. Walaupun begitu bank syariah harus tetap waspada. Banyak nasabah yang mengaku puas terhadap suatu merek atau perusahaan tapi tetap beralih ke perusahaan atau merek lain seperti yang ditemukan Garbarino dan Johnson (1999) dalam penelitiannya yang menemukan bahwa kepuasan tidak berpengaruh terhadap komitmen. Mereka mengusulkan bahwa kepuasan total adalah variabel antara yang penting antara komponen sikap, dan future intention. Peran kepuasan dalam memprediksi behavioral intention telah dibentuk dengan baik. Hasil penelitian yang dilakukan menunjukkan bahwa banyak nasabah yang puas terhadap produk atau jasa tetap beralih ke perusahaan lain yang memberikan penawaran yang lebih baik dan sebaliknya, banyak juga pelanggan yang tidak puas tetap membeli produk atau jasa dari perusahaan.

\section{Pengaruh Komitmen Afektif terhadap Komitmen Kontinu Nasabah Bank Syariah}

Pada tabel 31 menujukkan bahwa komitmen afektif berpengaruh terhadap komitmen kontinu nasabah bank syariah secara signifikan karena mempunyai CR-critical ratio 4,073 atau di atas 1,96 miliki koefisien jalur 0,800 dengan tingkat probabilitas 0,000 . Hal ini menunjukkan bahwa hipotesis yang menyatakan bahwa komitmen afektif berpengaruh positif dan siginifikan terhadap komitmen kontinu nasabah bank syariah terbukti kebenarannya (Ha diterima). Hasil ini mengindikasikan bahwa nasabah bank syariah telah memiliki komitmen yang mengarah pada perilaku nasabah untuk ingin menjalin hubungan atau kemitraan dalam jangka panjang dengan bank syariah. 
Kemitraan antara bank dengan nasabah lebih dari hubungan fungsional yang sederhana yang terbentuk untuk tujuan transfer komoditi. Nasabah menaruh dana (uang) ke bank dan nasabah perlu jaminan. Kemitraan antara bank dan nasabah sangat emosional dan ikatan-ikatan itu bisa sangat kuat. Semakin puas nasabah dengan jasa yang ditawarkan bank, semakin kuat ikatan emosional atau komitmen afektifnya. Nasabah yang tida puas, mungkin merasa dihianati dan secara emosional putus asa karena ikatan afektifnya yang kuat antara nasabah dengan bank telah diabaikan.

Tingkat komitmen telah ditemukan menjadi prediktor bagi keputusan untuk tetap berada dalam kemitraan (relationship). Komitmen telah dipandang secara dominan sebagai mempengaruhi keinginan untuk melanjutkan tindakan tertentu seperti mempertahankan hubungan dengan mitra. Nasabah komit pada suatu bank syariah terutama karena atribut produk islami, kualitas pelayanan dan reputasi bank syariah. Pada komitmen relasional, nasabah bersedia untuk melakukan usaha personal dan pengorbanan untuk mempertahankan hubungan kemitraan (relationship) yang ada.

Komitmen kontinu atau komitmen melakukan hubungan kemitraan (relationship) yang berkelanjutan merupakan keinginan untuk mengembangkan hubungan yang stabil, keinginan untuk mengorbankan kepentingan jangka pendek untuk mendapatkan keuntungan jangka panjang untuk mempertahankan kemitraan (relationship), dan pada stabilitas relationship.

\section{Pengaruh Komitmen Kontinu terhadap Loyalitas Nasabah Bank Syariah}

Pada tabel 1 menujukkan bahwa komitmen kontinu berpengaruh terhadap loyalitas nasabah bank syariah secara signifikan karena mempunyai CR-critical ratio 2,119 atau diatas 1,96 miliki koefisien jalur 0,478 dengan tingkat probabilitas 0,034 . Hal ini menunjukkan bahwa hipotesis yang menyatakan bahwa komitmen kontinu berpengaruh positif dan siginifikan terhadap loyalitas nasabah bank syariah terbukti kebenarannya (Ha: diterima). Hasil ini mengindikasikan bahwa nasabah bank syariah telah memiliki komitmen yang tinggi mengarah pada perilaku nasabah loyalitas nasabah pada bank syariah.

Pentingnya kemitraan (relationship) sebagai dasar untuk mempertahankan loyalitas nasabah menjadi dorongan yang besar untuk mengetahui halhal yang membuat nasabah menjadi loyal. Pemicu yang paling penting untuk 
membuat nasabah loyal adalah nasabah harus memiliki komitmen untuk menjalin hubungan dengan bank syariah adalah penilaian yang paling intangible, yaitu emosi pada saat berhubungan. Nasabah merasakan adanya ikatan emosional dengan suatu bank syariah. Nasabah sering mengatakan bahwa perasaan yang tumbuh saat melakukan transaksi adalah hal yang membuat mereka kembali atau bahwa kedekatan mereka dengan bank syariah adalah hal yang membuat mereka merasa enak bertransaksi disana. Ikatan emosional inilah yang membuat nasabah mempunyai keinginan yang kuat untuk terus menjalin hubungan atau kemitraan dengan suatu bank syariah. dan bahkan nasabah yang loyal akan cenderung memaafkan bank syariah jika terjadi ketidak sesuaian dengan harapannya.

Mereka juga mengakui adanya perasaan dekat atau kecintaan mereka terhadap bank syariah sehingga mereka memiliki suatu taraf kenyamanan dalam berurusan dengan bank syariah. Mereka mungkin sudah mulai menyebut bank syariah ini sebagai "bank-ku" karena mereka merasa bangga menjadi nasabah bank syariah. Kunci sukses bagi banyak perusahaan terletak pada transformasi hubungan kemitraan menjadi hubungan semacam ini. Pada saat inilah sebuah perusahaan berada pada jalur yang tepat untuk menciptakan hubungan sejati dengan pelanggan.

Nasabah ingin tetap menjalin hubungan dengan bank syariah karena merasa bahwa hubungan itu penting untuk dipertahankan. Moorman etal. (1992) mendefinisikan komitmen sebagai keinginan yang terus menerus untuk mempertahankan loyalitas. Kemitraan (relationship) yang bernilai menekankan keyakinan bahwa komitmen ada hanya ketika hubungan kemitraan (relationship) dianggap penting. Ini mengimplikasikan tingkat kewajiban yang lebih tinggi untuk membuat kemitraan (relationship) antara nasabah dengan bank syariah berhasil dan membuat masing-masing pihak puas dan memperoleh manfaat. Nasabah yang memiliki komitmen tinggi percaya bahwa mereka menerima nilai lebih dari hubungan yang ia jalin dan bersedia memberi sesuatu kepada bank syariah yang telah memberikan benefit kepada mereka.

Hasil penelitian ini mendukung penelitian yang dilakukan oleh Venetis dan Ghauri (2004). Dalam penelitiannya Venetis dan Ghauri menggunakan komitmen sebagai variabel antara yang memainkan peran penting dalam membentuk hubungan jangka panjang yang pada akhirnya akan terjadi loyalitas nasabah. Penemuan dalam penelitian ini menunjukkan bahwa 
komitmen kontinu berpengaruh signifikan pada loyalitas. Dengan kata lain Loyalitas dibentuk dari adanya komitmen kontinu dari pihak-pihak yang terlibat dalam hubungan kemitraan antara bank syariah dengan nasabah. Moorman et.al. (1993) menyatakan bahwa pelanggan yang komitmen melanjutkan hubungan dapat memiliki kecenderungan yang lebih besar untuk ingin tetap atau loyal menjalin hubungan dengan perusahaan karena kebutuhan mereka untuk tinggal konsisten dengan komitmen mereka. Nasabah bank syariah membuat komitmen dengan bank syariah mereka juga menunjukkan kemungkinan yang lebih kuat untuk terus atau loyal menjadi nasabah bank syariah. Oleh karena itu, ada kemungkinan untuk menggunakan jasa secara teratur dan mempertahankan loyalitas sepanjang jasa yang ditawarkan konsisten dan dapat diprediksi. Komitmen nasabah adalah bukti dari adanya emosi yang menstranformasikan perilaku pembelian berulang menjadi suatu loyalitas. Jika nasabah tidak merasakan adanya kedekatan dengan suatu bank syariah, maka hubungan antara nasabah dan bank syariah tidak memiliki karakteristik suatu hubungan. Ini berarti bahwa untuk membuat nasabah selalu loyal, diperlukan usaha yang lebih keras lagi. Bank syariah tidak hanya harus mampu memberi nilai dan benefit lebih untuk membuat nasabah memilih produk dan jasa yang ditawarkan bank syariah, akan tetapi juga terus-menerus melakukan berbagai upaya untuk mempertahankan nasabah.

\section{Pengaruh Kepuasan terhadap Loyalitas Nasabah Bank Syariah}

Pada tabel 1 menujukkan bahwa kepuasan berpengaruh terhadap loyalitas nasabah bank syariah secara signifikan karena mempunyai CR-critical ratio 1,985 atau di atas 1,96 miliki koefisien jalur 0,4 dengan tingkat probabilitas 0,047. Hal ini menunjukkan bahwa hipotesis yang menyatakan bahwa kepuasan berpengaruh positif dan siginifikan terhadap loyalitas nasabah bank syariah terbukti kebenarannya (Ha: diterima). Secara universal satisfaction dan reputation mempunyai hubungan positif, hal in sesuai dengan pendapat Cronin dan Taylor, ${ }^{78}$ Fornell, ${ }^{79}$ Sellnes, ${ }^{80} \mathrm{Yi}^{81}{ }^{81}$ Andreassen, ${ }^{82}$ Para-

\footnotetext{
${ }^{78}$ Cronin and Taylor, "Measuring Service Quality...."

${ }^{79}$ Fornell, C., "A National Customer Satisfaction Barometer...."

${ }^{80}$ Sellnes, Fred, "An Examination of the Effect of Product Performance..."

${ }^{81}$ Yi, Y., "A Critical Review of Customer Satisfaction,"
} 
suraman, ${ }^{83}$ Shemwell, ${ }^{84}$ Oliver ${ }^{85}$, Mowen, ${ }^{86}$ dan Rahman. ${ }^{87}$ Customer loyalty pada hakikatnya akan mencerminkan sikap yang brand loyalty. Adapun brand loyalty didefinisikan sebagai tingkat dimana konsumen mempertahankan sikap positif terhadap sebuah brand, memiliki komitmen dan berharap terusmenerus menggunakan atau memakai produk barang atau jasa dimasa yang depan. Dengan demikian brand loyalty dipengaruhi langsung oleh satisfaction pada brand yang dihimpun melalui waktu. ${ }^{88}$ Loyalitas konsumen merupakan tiket menuju sukses sebuah bisnis, konsumen yang loyal adalah konsumen yang puas. Untuk mencapai loyalitas konsumen, kepuasan merupakan syarat utama harus dipenuhi.

Pengalaman yang dialami langsung memiliki dampak pada brand reputation. Persepsi kualitas digabung dengan brand akan mendorong ketika konsumen mengalami performance quality yang tinggi, atau tidak diperkuat ketika konsumen mengalami kualitas yang rendah. Penelitian dorong ketika konsumen mengalami performance quality yang tinggi, atau tidak diperkuat ketika konsumen mengalami kualitas yang rendah. Sedangkan dalam penelitian Rahman ${ }^{89}$ menunjukkan ada pengaruh yang signifikan kualitas pelayanan terhadap kepuaan dan loyalitas nasabah bank syariah. Kualitas jasa (kualitas pelayanan) merupakan faktor yang paling kuat pengaruhnya terhadap kepuasan dan loyalitas nasabah bank syariah.

Konsep hubungan kausal antara kepuasan konsumen dan loyalitas, dimana konsep ini mempunyai dampak langsung pada loyalitas..$^{90}$ Fornell menyatkan bahwa kepuasan konsumen mempengaruhi perilaku membeli.91 Menurut Cronin dan Taylor ${ }^{92}$ terdapat korelasi yang kuat antara kepuasan dengan loyalitas. Untuk mencapai loyalitas, kepuasan merupakan syarat

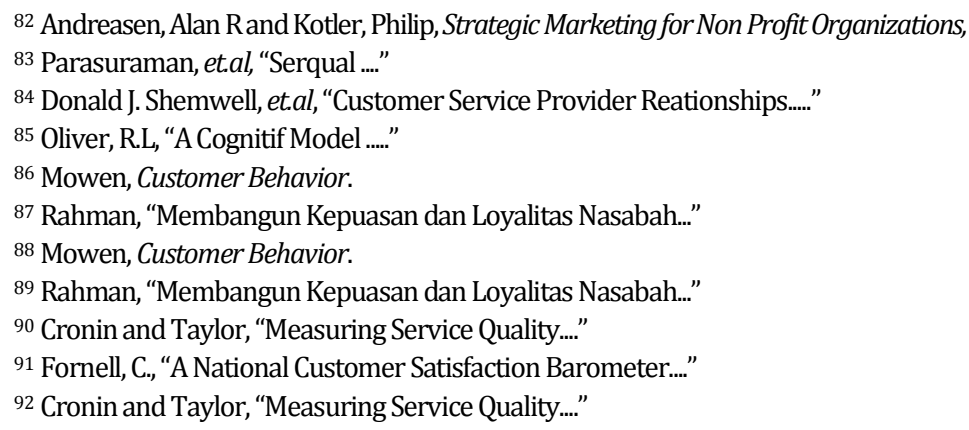


utama yang harus dipenuhi. Jadi untuk mencapai loyalitas nasabah, maka nasabah harus merasa puas dengan hubungan kemitraan yang terjalin antara nasabah dengan bank syariah. Karena loyalitas nasabah merupakan tiket menuju sukses semua bisnis, nasabah yang loyal adalah nasabah yang puas. Oleh karena itu bagi bank syariah yang ingin memenangi perasingan dan tetap bertahan dalam persaingan, syarat utama adalah memuaskan nasabah. Nasabah yang puas akan menceritakan kepaa keluarga, teman dan saudara akibat dari hubungan kemitraan yang ia jalin sehingga akan tercipta loyalitas nasabah.

\section{Kesimpulan}

Berdasarkan hasil penelitian yang telah diperoleh melalui kajian telaah pustaka dan hasil analisis data yang menggunakan metode SEM dalam program Amos versi 4.01, maka dalam rangka meningkatkan reputasi bank syariah agar dapat bersaing dalam industri perbankan, maka strategi yang harus dikembangkan bank syariah adalah meningkatkan kualitas pelayanan. Karena secara empiris pengaruh kulaitas pelayanan lebih kecil dari atribut produk islaminya. Pada hal dimasa yang akan datang, nasabah akan cenderung berperilaku rasional dalam menjalin kemitraan dengan bank. Oleh karena itu peningkatan kualitas pelayanan yang unggul (excellence) menjadi prioritas utama dalam mengembangkan startegi ke depan bank syariah. untuk mencapai kualitas pelayanan yang unggul dalam menghadapi persaingan dalam industri perbankan yang semakin ketat maka bank syariah harus memprioritaskan pada aspek-aspek rasional bukan emosioanal seperti pelayanan pendekatan shariah marketing yang cenderung aspek emosional. Sehingga kedepan aspek pelayanan yang menjadi prioritas adalah keamanan, kenyamanana kecepatan dan ketepatan karena hal ini akan menambah kepercayaan nasabah pada bank syariah. karena bisnis perbankan adalah bisnis kepercayaan, sehingga kepercayaan dapat dimulai dari peningatan pelayanan yang excellence.

Selain peningkatakan pelayanan yang excellence, pengambangan dan inovasi produk perlu ditingkatkan. Secara empris, pengaruh atribut produk islami lebih dominan dari kualitas pelayanan yang ditawarkan oleh bank syariah. Mengingat produk yang ditawarkan bank syariah sangat sensitif terhadap prinsip-prinsip syariah, maka sosialisasi terhadap penggunaan atau 
manfaat dari produk itu perlu dilakukan daripada mempertentangkan halal atau haramnya suatu produk bank syariah. Nasabah perlu mengetahui keterbukakan, transparasi terhadap produk dan manfaat apa yang didapat oleh nasabah jika menggunakan pproduk bank syariah. sosialisasi tentang manfaat atas produk bank syariah inilah yang lebih mengena daripada mempertentang halal atau haramnya suatu produk bank. Karena sebagian besar nasabah tidak paham tentang konsep-konsep fiqh yang dijadikan dasar untuk mengembangkan atau melakukan inovasi produk bank syariah. yang diperlukan oleh nasabah adalah apa manfaat atau keuntungan dari produk atau jasa yang ditawarkan oleh bank syariah jika dibanding dengan produk atau jasa bank konvensional, di sinilah letak strategi pengembangan bank syariah kedepan. Bagaimana pelaku bisnis atau uasaha bank syariah dapat mensosialisasikan dari produk yang ditawarkan, dan pakah keunggulan dari produk-produk yang berciriksahkan Islam jika dibanding dengan produk atau jasa dari bank lainnya.

Komitmen merupakan esensi yang pokok dari kesuksesan hubungan kemitraan yang baik dalam jangka panjang, dimana komitmen yang dikeluarkan oleh kedua belah pihak dalam pertukarannya dapat menjadi pondasi dalam membangun kemitraan. Dalam hubungan kemitraan, penekanannya dalam kemitraan dilakukan hubungan secara terus menerus. Kemitraan antara bank dan nasabah sangat emosional dan ikatan-ikatan itu bisa sangat kuat. Oleh karena itu peningkatan komitmen baik afektif maupun kontinu perlu diperhatikan oleh bank syariah. Dengan lebih empati dan respon terhadap kebutuhan-kebuthan dari nasabah maupun pennganan keluhan yang cepat akan meningkatkan kepuasan nasabah. Nasabah yang merasa puas akan lebih mempunyai komitmen menjaga hubungan kemitraan scara terusmenerus.

Untuk meningkatan hubungan kemitraan antara nasabah dengan bank syariah yang berorientasi pada kepuasan dan loyalitas nasabah, perlu dibangun suatu komitmen bersama antara nasabah dengan bank syariah baik melalui peningkatan kualitas pelayanan, inovasi produk, penambahan fasilitas layanan dan peningkatan reputasi bank syariah. Hubungan yang baik akan diterima dan dikenang oleh nasabah, dan nasabah akan menceritakan hubungan yang baik tersebut kepada saudara, teman, keluarga. Dengan sendirinya stimuli yang didapat dari hubungan kemitraan tersebut akan 
terjalin loyalitas. Nasabah yang loyal adalah nasabah yang puas, nasabah yang puas belum tentu loyal. Oleh karena itu orientasi yang dibangun dari hubungan kemitraan berakhir pada terjadinya loyalitas nasabah pada bank syariah. Nasabah yang sudah memiliki loyal akan memberikan maaf kepada bank syariah apabila sesekali melakukan hal yang tidak diharapkan. Hubungan yang telah dibangun dengan nasabah yang memiliki keinginan yang kuat untuk menjalin hubungan sejati merupakan jaminan bagi suatu bank syariah.[w] 


\section{BIBLIOGRAFI}

Aaker A.D., Keller K.L, “Consumer Evaluations of Brand Extentions," Journal of Marketing, January 1990.

Andreasen, Alan R dan Kotler, Philip, Strategic Marketing for Non Profit Organizations, New Jersey: Pearson Education International Inc., 2003.

Bacon, L,D., Using Amos for Structural Equation Modeling in Market Research, Lynd Bacon \& Assocates SPSS Inc., 1997.

Bailey, Atherson dan Klemmack (1982) dalam Soehartono W., Metode Penelitian Sosial, Bandung: Remaja Rosdakarya, 1998.

Citra Fistylia, "Analisis Pengaruh Marketing Syariah dan Etika Pemasaran terhadap Kepuasan Nasabah pada Bank Muamalat di Kota Semarang," Tesis, tidak dipublikasikan, Semarang: Unissula Semarang, 2008.

Cronin and Taylor, "Measuring Service Quality: A Reexamination and Extension," Journal of Marketing, Vol. 56, No. 3, 1992, pp. 55-68.

Donal J. Shemwell, Ugur Yavas \& Zaynep Bilgin, “Customer Service Provider Reationships: an Emperical Test of Model of Service Quality, Satisfaction and Reationships Oriented Outcomes," International Journal of Service Industry Management, Vol. 9, No. 2, 1988, pp. 155-168.

Engel, James F, Roger D. Blackwell and Paul W. Miniard, Consumer Behavior, New York: Dryden Press, 1993.

Ferdinan, A., Structural Equation Modeling dalam Penelitian Manajemen, Semarang: Badan Penerbit Universitas Diponegoro, 2004.

Fornell, C., "A National Customer Satisfaction Barometer: The Swedish Experience," Journal of Marketing, Vol. 56, 1992.

Gottlieb, J.B., Grewal, D. and Brown, S.W., "Consumer Satisfaction and Perceived Quality: Complementary or Divergen Construct? Journal of Applied Psychology. Vol. 99, No. 6, 1994, p. 875-885.

Glock, C.Y., Religion and Society Intension, Chicago: Rand McNally, 1965.

Iqbal, Z, "Islamic Financial System", Finance \& Develpoment, Juni 1997.

Kertajaya, Hermawan dan Sula, M. Syakir, Syariah Marketing, Bandung: Mizan Pustaka, 2006.

Walisongo, Volume 19, Nomor 1, Mei 2011 
Mowen, J.C, Customer Behavior, New Jersey: Prentice Hall Inc., 1995.

Oliver, R.L, "A Cognitif Model of the Antecedents and Concequences of Satisfaction Decisions," Journal of Marketing Research Vol. 17, No. 4, November, 1980, pp. 46-69.

Parasuraman, Valarie Zaithaml and Barry, "Serqual: A Multiple-Item Scale of Measuring Cunsumer Perceptions of Service Quality, Journal of Retailing, Vol. 64, Spring 1988, pp. 12-40.

Parasuraman, Valarie Zaithaml, Berry and Leonard, "A Conceptual Model Of Service Quality and Implication for Future Research', Journal of Marketing, 49, 1985, pp. 41-50.

Rahman, "Membangun Kepuasan dan Loyalitas Nasabah Melalui Atribut Produk, komitmen Agama, Kualitas Jasa dan Kepercayaan pada Bank Syariah (Studi Pada Bank Muamalat Cabang Semarang)," Jurnal Penelitian Walisongo, Pusat Penelitian IAIN Walisongo, 2003.

Kotler, Philip dan Gary Armstrong, Dasar-dasar Pemasaran, Jilid 1, Jakarta: PT. Indeks Gramedia, 2003.

Sekaran, Uma, Research Methods for Business, A Skill Building Approach, Singapore: John Wiley and Sons Inc. , 2003.

Sellnes, Fred, "An Examination of the Effect of Product Performance on Brand Reputation, Satisfaction and loyalty," European Journal of Marketing, Vol. 27 No. 9, 1993, pp. 19-35.

Shapiro, A.C., Modern Corporate Finance, New York: MacMillan Publishing Co., 1990.

Solimun, Multivariate Analysis, Structure Equation Modelling (SEM), Lisrel dan Amos, Malang: Penerbit Universitas Negeri Malang, 2002.

Straube, Peter, "Why Customer Satisfaction May Not Mean Loyalty, Nation's Restaurant News, Vol. 31, July 1997, pp. 32-36.

Tse, David K. and Peter C Wilton, "Models of Customer Satisfaction Formation: An Extension," Journal of Marketing Research Vol. 25, May 1988; p.p204-212.

Yi, Y., "A Critical Review of Customer Satisfaction, in Zeitahml VA (et.al)," Review of Marketing, Chicago: American Marketing Ascociation, 1988, pp. 68-123.

Yi-Ting Yu and Alison Dean, "The Contribution of Emotional Satisfaction to Customer Loyalty," International Journal of Service Industry Management, 2001.

Yuana Tobing, "Hubungan Antara Performance Quality dengan Customer Oriented," Tesis, Semarang: Universitas Diponegoro, 2000. 
Zeithaml, V.A., "Consumer Perceptions of Price, Quality, and Value : A MeansEnd Model and Synthesis of Evidence," Journal of Marketing, Vol. 52, July 1988, pp. 2-22.

Zeithaml, Valerie A., \& Bitner, Mary Jo., Service Marketing, Singapore: Mc.GrawHill, 1996. 
